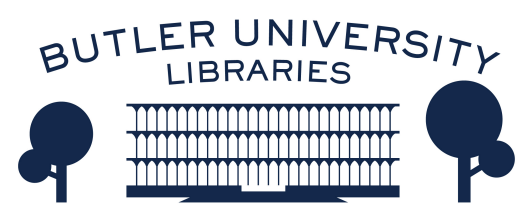

Journal of Hindu-Christian Studies

January 2004

\title{
Book Review: "The Quest for the Origins of Vedic Culture: The Indo-Aryan Migration Debate"
}

\author{
Eliza Kent
}

Follow this and additional works at: https://digitalcommons.butler.edu/jhcs

Part of the Religion Commons

\section{Recommended Citation}

Kent, Eliza (2004) "Book Review: "The Quest for the Origins of Vedic Culture: The Indo-Aryan Migration Debate"," Journal of Hindu-Christian Studies: Vol. 17, Article 17.

Available at: https://doi.org/10.7825/2164-6279.1326

The Journal of Hindu-Christian Studies is a publication of the Society for Hindu-Christian Studies. The digital version is made available by Digital Commons @ Butler University. For questions about the Journal or the Society, please contact cbauman@butler.edu. For more information about Digital Commons @ Butler University, please contact digitalscholarship@butler.edu. 


\section{The Quest for the Origins of Vedic Culture: The Indo-Aryan Migration Debate. Edwin Bryant. New York: Oxford University Press, 2001, xi + 371 pp., maps il.}

WERE the Noble Ones who composed the Vedas direct descendents of nomadic tribes who migrated into India from somewhere west of the Khyber Pass between 1500 and 1200 BCE? Or were they a people indigenous to India, perhaps even contemporaneous with the technologically sophisticated creators of the Indus Valley Civilization? The answers to these questions are relevant not only to Indologists, historians of early India, and other scholars in South Asian studies, many of whom have built careers on "the assumption of an external origin for Vedic Culture, but also to politically engaged scholars and activists in India seeking to bolster (or challenge) a vision of the modern Indian nation-state as functioning primarily for the benefit of Hindus. As a result, the debate over the homeland of the IndoAryans has become exceedingly polarized. According to Bryant the majority of historians in India now favor the Indigenous Aryan view, finding perfectly plausible that the Indo-Aryan speaking people did not come from outside India, but rather were originally from somewhere on the Indian subcontinent, probably the Northwest. Meanwhile, in Britain, Europe, Canada and the United States, scholars and textbooks for the most part accept the Aryan Migrationist theory. Some even treat with indulgence the now widely discredited Aryan Invasion hypothesis, which pictured blonde-haired, blue-eyed Aryans swarming across the steppes to plunder the dark-skinned, snubnosed dasas in India. I confess I have until recently been among the Migration Theory loyalists who pay only glancing attention to opposing points of view in this debate. Overheated exchanges on scholarly listservs had led me to regard the arguments against the Aryan Migration hypothesis as the fantasies of disgruntled cranks and covert (and sometimes overt) Hindu nationalists. When the evidence for or against a particular theory is so scanty and the analysis of it by specialists so complex, one inevitably relies on the authority of experts. Edwin Bryant's thorough re-examination of the evidence and arguments surrounding the origins of Indo-European culture offers a healthy reminder of the perils of this kind of intellectual shortcut.

The first chapter discusses the beginnings of the quest for an Indo-Aryan homeland in the $18^{\text {th }}$ century "discovery" of Sanskrit and the resulting challenges to the biblical worldview. It also helpfully reviews several prevailing theories about the IndoAryan homeland. The second chapter discusses how Indians living under British colonialism appropriated European theories about the Aryans for a variety of purposes. This chapter anticipates the more thorough discussion of the political uses of the Indigenous Aryan argument in present-day India that the author undertakes in the last chapter. The middle ten chapters present how scholars in a variety of fields use evidence to advance or undermine the Aryan Migration hypothesis. Bryant has here done us all an enormous favor by sorting through a formidable amount of scholarship spanning fields as diverse as philology, comparative linguistics, historical linguistics, linguistic paleontology, IndoEuropean studies, astronomy, archeology, paleogeology, and archaeozoology. Drawing on a wide array of experts, including many whose work very rarely surfaces in mainstream English-language scholarship, he demonstrates how Indigenous Aryanists and Aryan Migrationists, proceeding from different assumptions, can arrive at diametrically opposed interpretations of the same evidence even while using the same 
methods. He provides dense but generally lucid summaries of literally dozens of controversies, such as whether or not the remains of horses found in Harappan sites can be positively identified as those of a true horse (Equus caballus Linn) or a more intractable creature such as the domestic ass (Equus asinus) or the hemione (Equus hemionus). Readers will probably gravitate to those controversies with which they are most familiar. One of the few drawbacks of the book, in fact, is Bryant's exhaustive, and sometimes exhausting, review of all sides of every debate. Especially in those controversies with which the reader is less familiar, one finds oneself grasping at Bryant's rare assertions of opinion like a man drowning in a sea of facts.

Of particular interest to readers of this journal will be the first chapter. The "discovery" of Sanskrit by $18^{\text {th }}$ century European scholars, along with other textual and archeological evidence of the antiquity of the human race, provoked a serious questioning of the Biblical narrative of human history. How could the internal claims of Sanskrit texts for a created universe hundreds of thousands of years old be reconciled with the much shorter chronology of the Earth derived from Christian scripture? Sir William Jones himself went to great lengths to demonstrate that there was no great contradiction between the "chronologies of early human history extractable from Hindu and Christian scripture. Even after the social pressure to confirm the validity of Biblical accounts of history waned in the nineteenth century, other elements of the biblical worldview persisted. Scholars of intellectual history will be interested in his argument that the paradigm from Genesis of a single postdiluvian family dispersing and becoming linguistically differentiated over time survives to the present day as the founding assumption of Indo-European studies.

This kind of tension between different epistemological frameworks is a recurring theme in this work. For example, Bryant notes the irony in the fact that just as some eighteenth-century Christian scholars sought to use the science of linguistics to prove the historicity of scriptural narratives, so are some Hindu scholars today employing archeology and linguistics to ratify the truths of the revealed Vedas. When satellite photographs and archeological digs reveal the massive dried-up bed of the Sarasvati river, celebrated in over sixty Rgvedic hymns, in exactly the place. where the Rgveda locates it, the satisfaction among Indigenous Aryanists is palpable. First, this finding refutes Western scholars who have said that the Sarasvati was just a myth, at best the result of the Vedic authors' memories of an even greater river back in their homeland somewhere in the Caucasus, or Anatolia, or Armenia, or any place but India. Second, the discovery of the Sarasvati seems to clearly demonstrate the veracity of Vedic revelation. This is not to say that Indian scholars today are manipulating scientific evidence in order to preserve the authority of religious text, while scholars in the West gave that up two centuries ago. Rather, one of the effects of Bryant's study is to show how tenaciously all scholars cling to their favorite arguments and narratives, whatever their grounding source of authority, sometimes bending over backwards to argue away contradictory evidence:

While stating his sympathies with the anti-imperial sentiments conveyed by the Indigenous Aryan argument, Bryant deftly distances himself from those who seek to use it to promote Hindu nationalism. The author is well aware of the way in which scholarly interpretations of evidence are themselves interpreted within a volatile socio-political environment in India, in which the assertion that the Vedas were composed by people native to India is used to privilege adherents of religions that are seen as flowing from them, and to disprivilege those that do not. Yet he is equally sensitive to another implication of the Indigenous Aryan argument, not 
sufficiently recognized by its opponents, namely that the effort to re-examine the Aryan Migrationist argument is also an anticolonial, anti-imperialist project insofar as it entails a challenge to versions of early Indian history scripted by India's former colonial masters.

This is, after all, also a book about the politics of scholarship. From the British administrators' use of theories about the connection between Sanskrit and European classical languages to legitimate colonial rule to the use of evidence of an IndoEuropean homeland in South Asia by Hindutva ideologues to bolster a sense of Hindu superiority, Bryant illuminates how narratives about the past are employed to promote particular political agendas. And while such an endeavor is often undertaken in order to promote one agenda or undermine another, Bryant avoids this with his scrupulous faimess to all sides of the debate. Notably, he goes to great lengths to advocate against what he calls Indological McCarthyism - the knee-jerk branding of anyone who opposes the theory of Aryan Migration as a communal bigot. In the process, he manages to bring a breath of fresh air into the sometimes fetid chat-room of contemporary academia. Edwin Bryant's lucid and thorough re-examination of the question of the origins of Vedic culture is a must read for any teacher who begins his or her courses on Indian religions with a discussion of the Indus Valley Civilization and the Vedas. It is an exemplar of one of the core values of critical scholarship: the willingness to question one's own cherished assumptions in the face of points of view very different from one's own.

\section{Eliza Kent}

Colgate University

\section{Indian Critiques of Gandhi. Harold Coward, ed. Albany, N.Y.: State University of New York Press, 2003, 287 pp.}

MANY in recent years have been dismayed at the seemingly radical eclipse of Gandhian ideals in India and the extraordinary success of ideologies and movements militantly antiGandhian in method and outlook. Witness, among other indicators, the Pokaran II nuclear tests (1998) and the recent (February 2003) installation in the Central Hall of India's Parliament of a portrait of "freedom fighter" V. D. Sarvarkar, virulent critic of Gandhi and master theoretician of Hindu communalism.

Given such developments, Harold Coward's edited volume Indian Critiques of Gandhi is timely and of great interest. The book opens with an introduction by Coward outlining Gandhi's involvement with the independence movement and its major figures during 1920-40. It is a valuable overview, especially for students or general readers whose familiarity with the story stems from popular accounts of the
Mahatma's life (or Attenborough's Gandhi), from which one would scarcely gather that he had opponents with serious objections to his moral/religious vision and his methods. Part one of the volume examines Gandhi's interactions with major figures in the Indian independence movement, including chapters on Nehru (Robert D. Baird), Ambedkar (Harold Coward), Besant (Joy Dixon), Aurobindo (Robert N. Minor), and Tagore (T. S. Rukmani). The chapters in part two focus on Gandhi's relations with groups, covering the Hindu Mahasabha (Ronald Neufeldt), Christians in India (Timothy Gorringe), Sikhs (Nikky-Guninder Kaur Singh), Muslims (Roland E. Miller), and the "Hindi-Urdu question" (Daud Rabhar), which was to be one of the factors leading to partition in 1947. (It is rarely possible to attain complete coverage in a volume like this; the editor apologizes for having no chapters on players such as Subhas Chandra 